DOI: https://doi.org/10.32839/2304-5809/2021-4-92-10

УДК 378:371.-147.

Заруцька В.О., Жиленко М.В.

Київський національний університет імені Тараса Шевченка

\title{
ДИДАКТИЧНІ НАСТІЛЬНІ ІГРИ ЯК ІНСТРУМЕНТ ПІДВИЩЕННЯ ЕФЕКТИВНОСТІ ВИКЛАДАННЯ У ВИЩІЙ ШКОЛІ
}

Анотація. Стаття присвячена визначенню сутності дидактичної настільної гри, розкриттю особливостей їх застосування у організації викладання у вищій школі. Розкривається актуальність використання настільних ігор у освітній діяльності, аналізуються основні переваги та ризики, які можуть виникнути у процесі впровадження. Визначається ставлення студентів до використання освітніх настільних ігор та рівня вдоволення аудиторії якістю навчальних занять. Деталізуються умови використання даної форми навчання та акцентуеться увага на необхідності розробки практичних рекомендацій для викладачів вищої школи, які б покроково описували процес створення настільної гри, адаптованої під вивчення конкретної дисципліни. Аналіз вітчизняних та іноземних наукових публікацій за тематикою дослідження, визначення основних прогалин на українському освітньому ринку в сфері використання настільних ігор. Ми визначили, що дидактична настільна гра: срормуе стійкий інтерес до навчальної діяльності; розвине навички роботи у команді та здатність до співпраці; надасть знання, що передбачені навчальною програмою, у доступній та веселій формі; допоможе сформувати загальні та професійні компетентності; зніме психоемоційну напругу у академічному колективі, згуртуе членів команди, подолає бар'єри у спілкуванні ; створить ілюзію реальності під час гри, коли прийняті рішення, здається, маю справжній вплив на твоє життя; розвине критичне та аналітичне мислення, емоційний інтелект та креативність; за розумного застосування - сформує навик розвитку партнерських взаємин замість загострення конкуренції.

Ключові слова: настільні ігри, дидактичні настільні ігри, викладання у вищій школі, ефективність викладання, якість освіти, розробка та впровадження.

Zarutska Victoria, Zhylenko Mykola Taras Shevchenko National University of Kyiv

\section{DIDACTIC BOARD GAMES AS A TOOL TO INCREASE THE EFFICIENCY OF TEACHING IN HIGHER EDUCATION}

Summary. The article is devoted to defining the essence of didactic board game, revealing the peculiarities of their application in the organization of teaching in high school. The relevance of the use of board games in educational activities is revealed, the main advantages and risks that may arise in the implementation process are analyzed. The attitude of students to the use of educational board games and the level of audience satisfaction with the quality of classes is determined. The conditions of using this form of education are detailed and attention is focused on the need to develop practical recommendations for high school teachers, which would describe step by step the process of creating a board game adapted to the study of a particular discipline. Analysis of domestic and foreign scientific publications on the research topic, identification of the main gaps in the Ukrainian educational market in the use of board games. We determined that the didactic board game: will form a lasting interest in educational activities; develop teamwork skills and ability to cooperate; provide the knowledge provided by the curriculum in an accessible and fun way; will help to form general and professional competencies; relieve psycho-emotional tension in the academic team, unite team members, overcome barriers to communication; create the illusion of reality during the game, when the decisions made seem to have a real impact on your life; develop critical and analytical thinking, emotional intelligence and creativity; with reasonable use - will form the skill of developing partnerships instead of intensifying competition. Board game, in our opinion, will allow you to conduct classes with students, providing knowledge, developing skills and at the same time working with the psycho-emotional sphere of the individual. We tried to focus on the moral side of involving game elements in learning, how it affects the behavior and emotions of the participants involved, whether there are any changes and how we are able to track them. We aimed to present board games as a relatively new educational tool that every teacher is able to use in the process of organizing the teaching of a particular discipline. The tool, which is relatively easy to use, does not require significant resources and has a long-term effect on the behavior and emotions of the students involved. Learning material is always better remembered if it touches emotions. And the game gives such an opportunity. It allows you to both study and enjoy the educational process. This is why researchers, when talking about the difference between educational board games and ordinary board games, first of all say that the former answer the question HOW do we convey information to the player, HOW do we teach, instead of focusing solely on what we offer participants.

Keywords: board games, didactic board games, high school teaching, teaching efficiency, quality of education, development and implementation.

$\Pi$ остановка проблеми. Останні декілька років можемо спостерігати цікаву тенденцію, згідно якої багато організацій, фондів, шкіл, що займаються навчанням різних категорій населення чи просвітницькою діяльністю, розробляють власні настільні ігри, та завдяки їм формують необхідні навички та вміння, будують у світоглядах людей уявлення про складні процеси доступною мовою, або просто залучають до ефрективної комунікації. Варто відкрити навіть сторінку популярного серед молоді месенджеру - Інстаграм, і таргентована реклама одразу 
запропонує тобі великий асортимент ігор: серед них і на розвиток критичного мислення, і на подолання ніякових пауз при першому знайомстві, і на руйнування гендерних стереотипів тощо. То чому б не взяти те, чим користуеться, без перебільшення, увесь світ і помістити у сфреру, яка фрактично створена для креативності та інновацій? Ігри у навчанні мають бути орієнтовані не лише на дошкільнят та школярів, але і на дорослих людей, які здатні грунтовно вести дискусію, чітко стежити за дотриманням іншими учасниками правил, водночас зберігаючи емоційність та бажання бути першим.

Нами було проведене, впродовж листопада 2020 року, анкетування студентів фракультету психології, Київського національного університету імені Т. Шевченка, з метою виявлення стану якості викладання дисциплін та можливого включення у освітній процес ігрових технологій. Одним із її питань була спроба визначити рівень вдоволення студентами (теперішніми та колишніми) організацією навчальних занять у вищій школі. Половина опитаних - 50\% відповіли категорично, що ïx не влаштовуе наразі організація їх навчальних занять. 37,5\% відповіли, що скоріше не подобаеться, аніж подобається, і 12,5\% обрали варіант, що передбачав лише часткове вдоволення їх потреб та запитів. Жоден із опитаних не обрав варіантів «так, цілком задовільняє», що свідчить про безперечну необхідність внесення змін до традиційної організації занять в університеті через їх низьку едективність та відсутність мотивації.

Студенти зазначали, що їм не вистачає занять, які були б наближені до майбутньої профресійної діяльності, інтерактивних технологій, творчих та практичних завдань, і у цьому ігри можуть бути корисними.

Нас також цікавило, чим може бути корисним використання елементів гри у освітньому процесі. Опитані зазначили, що це підвищить едективність засвоєння теоретичних знань, покращить комунікацію всередині академічної групи, яка може страждати від надмірної конкуренції за місце у рейтинговій системі. Включення у освітній процес ігрових елементів дозволить підвищити мотивацію студента до навчальної діяльності, викличе у нього істинний інтерес та захоплення, перетворить його у активного суб'єкта освітньої діяльності, що реалізуе в життя концепцію особистісно-орієнтованого навчання.

Ми запитали у студентів чи взяли б вони участь у проведенні настільної дидактичної гри у їх академічній групі, і 75\% респондентів відповіли, що із задоволенням долучились, що свідчить про зацікавленість студентами у такій фopмі навчання.

Аналіз останніх досліджень та публікацій. Якщо взяти за основу праці вітчизняних вчених, то до використання ігрових технологій у своїх наукових доробках звертались А. Вербицький, Д. Ельконін, В. Комаров, В. Рибальський, Л. Вишнякова та інші. Можливість розробки та використання дидактичних настільних ігор у процесі викладання згадуеться у публікаціях спільного проекту urban curators та Mistosite (M. Грищенко, О. Дядікова), наукових статтях таких авторів як Н.Ю. Ляшок, А.А. Тарасенко, С.Р. Макоїд, А.О. Попова, М.В. Щеголь.
Варто зазначити, що в просторі української освіти не надто поширено поєднувати настільні ігри із освітою та відшуковувати їх точки дотику. Зате, вивчаючи праці наших зарубіжних колег, можна помітити, що вони вже достатньо давно займаються дослідженням даної теми та створили не один десяток ігор, які можна використовувати як у вищій школі, так і у навчанні дорослих, зокрема у післядипломній освіті. Цю тему вивчають Anderson E.F., McLoughlin L., Liarokapis F., Peters C., Petridis P., Hamari J., Koivisto J., Pakkanen T. та інші.

Виділення невирішених раніше частин дослідження. Незважаючи на значну зацікавленість цією темою науковців, наявністю великої кількості праць, присвяченій цій проблематиці, досі залишаються прогалини у питанні вдосконалення даної технології, а головне - у її впровадженні.

Використання дидактичних настільних ігор у процесі викладання, в українському сегменті, є малодослідженим, це порівняно новий метод активізації освітнього потенщіалу майбутніх педагогів, а така форма взаємодії викладача із студентами обєеднує у собі найкращі риси інших методів - рольових та імітаційних ігор, брейншторму, дискусії тощо. На українському ринку кількість подібних розробок можна порахувати на пальцях однієї руки, хоча вони можуть цілком замінити педагогічні задачі.

Мета статті - розкрити сутність використання дидактичної настільної гри як механізму підвищення ефрективності викладання у вищій школі, визначити основні переваги та ризики, що виникають під час їх реалізації у процесі проведення семінарських занять.

Вона деталізуеться у завданнях:

- проаналізувати поняття дидактичної настільної гри, їі різновиди та умови використання;

- визначити особливості включення настільних ігор у освітній процес вищої школи;

- перелічити переваги та недоліки даного методу навчання

Виклад основного матеріалу. Настільні ігри є для більшості давно відомою формою заповнення вільного часу, їх полюбляють грати як у великих компаніях, так і лише удвох. В класичному варіанті, вони передбачають наявність ігрового поля, картки, кубик, що надає можливість пересуватись ігровим простором та картки для розпізнавання учасників. Стандартною метою гри є проходження гравцями конкретного відрізку шляху в межах стратегії та прийти першим до фінішу з найкращим результатом із можливих.

Настільні ігри можна поділити на типи за видом взаємодії учасників у ній [1]:

1. Ігри - кооперації. Усі учасники є єдиною командою, що працюе заради досягнення спільного результату, який попередньо визначається та визнається кожним із присутніх. Перемога команди чи її поразка є спільним результатом.

2. Ігри - коаліції. На початку гри кожен грає сам за себе, намагаючись отримати максимальну вигоду для свого персонажа, але, у процесі, учасники починають об'еднуватись у мікрогрупи, щоб вкупі протистояти супротивникам. Якщо гра не є ретельно організованою, то існує можли- 
вість, що програє учасник, який не приєднався до кожної із коаліцій або ж коаліція, в якій найменше гравців. Цей тип гри наочно показує, що грати із кимось у команді більш виграшно, аніж сподіватись виключно на власні ресурси.

3. Команда проти команди. Учасників гри об'єднують у дві чи більше груп, які протистоять один одному, упродовж усієї гри. Але кожен гравець робить індивідуальні кроки та приймає самостійні, автономні рішення. Виграш чи поразка команди фріксується за першим учасником, який переміг або програв. Виграш команди у такій грі також залежить від їі згуртованості. Буває і таке, що правила забороняють учасникам однієї групи спілкуватись та домовлятись про спільну стратегію введення гри, і тоді важливо, щоб гравці були здатні зрозуміти іншого члена команди без слів та працювали злагоджено.

4. Кожен сам за себе. Для кожного гравця усі учасники є конкурентами. Перемагає один і його основна мета - обіграти усіх інших.

Стандартна кількість учасників гри - від двох до восьми людей. Іноді бувають винятки - ігри для більшої кількості людей, або ж навіть такі, де є один учасник - людина, яка грає проти самої гри [3].

Середній час тривалості гри від 40 хвилин до 3 годин. Зазвичай, настільні ігри передбачають взаємодію у реальному часі, що викликає деякі труднощі у період карантину та дистанщійної освіти. Але ми, все ж таки, переконані, що найближчі десять років онлайн-навчання не замінить повністю очне, а лише підсилить мотивацію студентів до реальних зустрічей та спілкування.

Дидактичні настільні ігри можуть мати один, або декілька сценаріїв розгортання. Для того, щоб покращити якість та едективність процесу гри, наприкінці неї бажано поспілкуватись із учасниками стосовно їх вражень від процесу гри, результату, спілкування, отримати зворотній зв'язок, можливо звернути увагу на якісь певні недоліки, щоб скорегувати їх у подальшому.

Для настільної гри, як і для будь-якої іншої, потрібен ведучий або модератор [2]. Це може бути хтось із гравців, або людина ззовні, стороння від команди. Його завданням є спостереження за процесом гри та його фріксація, консультування стосовно правил, слідкування за їх дотриманням та забезпечення рівних умов участі. Модератор так само попереджуе конфрлікти, які можуть виникнути під час гри, намагаеться вирішити їх та створити безпечну психологічну атмосферу, в якій кожен може почувати себе захищено, затишно та відкрито, а по завершенню гри, допомагае обмінятись емоціями та підводить підсумки роботи у команді.

Настільні ігри використовують задля [1]:

- Просвітництва та навчання. Під час спільного досягнення мети кожен учасник вчиться роботі у команді, розумінню думок та емоцій інших людей, їх стратегій поведінки, та виробляе власні. Гра допомагає розвинути навички критичного та стратегічного мислення, підвищуе пізнавальний інтерес та вчить взаємодіяти із різноманітними категоріями людей, іноді вирішуючи конфрліктні ситуації. Кожен із учасників настільної гри форомуе в собі такі загальні компетенції як: вміння вести перемовини та взаємодіяти із людьми, включатись у конструктив- ний діалог, брати відповідальність за прийняті рішення та діяти у нестандартних умовах, бути гнучким, аналізувати власну та чужу поведінку, робити висновки та діяти на їх основі. Тим паче, у грі, якщо ми говоримо про дидактичні настільні ігри, які стали популярними за останні 5 років, закладене певне спеціалізоване знання, яке розробники хочуть донести до гравців. Це може бути щось про історію міста (є така гра про Львів) чи його спільноти, потреби різних категорій населення, управління (як от гра «Світ громад» про організацію діяльності ОТГ), елементи педагогічної майстерності чи про основні професійні компетентності.

- Симулящіï реальних процесів. Настільна гра використовується як захищений простір для проживання реальної ситуащії чи вирішення практичних завдань, які подібні до справжнього життя і можуть відображати, наприклад, профресійні випадки, які можуть трапитись під час виконання посадових обов'язків. Така гра дозволяє змоделювати конкретні ситуації та процеси, а також опрацювати якими ж можуть бути наслідки рішень та дій учасників. Одразу ж побачити їх вплив на ігрову (реальну) ситуацію. Наприклад, симуляція розподілу ролей у освітньому процесі (ти - викладач, ти - студент, ти - мама студента), із необхідністю знаходження спільної мови та реалізації спільних проектів. Яким чином Ви, як викладач закладу вищої освіти, будете контактувати із батьками студента, що постійно пропускає заняття? Як ви, на місці матері (батька) студента, відреагуете на ситуацію? Ваші покрокові дії?

- Побудови команди. Це чудова можливість познайомитись у неформальних умовах, коли не відчуваєш потужного впливу суспільних правил та ієрархії один на одного. Гра - це невимушене, легке, доброзичливе спілкування, яке створює відчуття, що ти - цінний та вагомий для присутніх людей. Участь у грі дозволяє краще вивчити стратегії поведінки один одного та, можливо, скорегувати власні, внаслідок взаємовпливу учасників команди. Ведучий може виявити формальних та недормальних лідерів та основні механізми об'єднання у групах, що значно покращить комунікацію всередині колективу, зміцнить його.

- Прогнозування майбутньої профресійної діяльності - побудова стратегічних сценаріїв майбутнього.

Ігри дозволяють визначити людські стратегії прийняття рішень, людську поведінку та мотивацію здійснення тих чи інших вчинків. Настільну гру можна використовувати задля передбачення потенційних конфліктних ситуацій та виявлення аутсайдерів. Гра створюе безпечний простір, де можна обговорити хвилюючі теми - упередження, стереотипи, образи та пропрацювати їх. Вона дає змогу вивчити потреби суб'єктів ігрової взаємодії, їх бачення професійної діяльності у майбутньому, ролі, які вони виконують на даному етапі розвитку групи і яку позицію займають у колективі.

- Знайомства між собою та для відпочинку (рекреаційно - дозвіллєва фрункція гри). Настільна гра допомагає створити невимушену, неформальну атмосфреру між людьми, побудувати довірливі взаємини. Гравці можуть краще позна- 
йомитись між собою, поспілкуватись, відпочити від напруженої розумової праці, відволіктись, наповнено та корисно провести час. Група отримує спільний досвід, який позитивно впливатиме на її розвиток.

Настільні ігри, як і будь-які ігри, мають свої переваги та недоліки.

До переваг настільних ігор ми можемо віднести [4]:

- Вони є захоплюючи та не викликають у гравців значного напруження. Участь у них не потребує від людини багато зусиль та особливої підготовки.

- Вони є візуально привабливими, що стимулюе пізнавальну активність учасників.

- Їх можна використовувати як основний, так і додатковий інструмент проведення семінарського заняття. Додати до викладання дисципліни лише один ігровий елемент, або провести гру цілком.

- Настільні ігри є простими у використанні, не завжди навіть потребують модератора ззовні, ним може стати хтось із учасників.

- Така гра передбачає розкриття запрограмованих сценаріїв, створення різноманітних ситуацій, що наближені до реальності. Успішне вирішення таких практичних завдань, проживання змодельованих ситуацій дозволяє, залученим у них, відчути цінність власної діяльності, впевненість у наявних знаннях та наснагу для подальшого навчання.

- Вони налагоджують комунікацію всередині групи, це чудова можливість більше дізнатись один про одного.

До слабких сторін використання настільних ігор як механізму вдосконалення якості вищої освіти ми можемо внести:

- Необхідність значних витрат. Розробка нової гри потребує ресурсів: часових (це може зайняти до кількох місяців, та навіть років) - розробка, апробація, введення у експлуатацію може затягнутись за тривалістю, людських (залучення дизайнерів та генераторів ідей, друкарів, спонсорів, групи для досліджень), технічних ( наявність комп'ютера, принтера, відповідних програм для графрічного дизайну тощо), і звісно ж - фрінансових (чим менше примірників гри буде, тим гра буде більш вартувати).

- Потреба у постійному залученні учасників протягом усієї гри, фрокус на ігровому процесі. Відмова одного із учасників продовжувати гру може призвести до її передчасного завершення. Плануючи проведення гри, необхідно враховувати рівень мотивації учасників та кількість часу, що є у доступі. Гра не повинна бути надто затягнута, але і не надто швидка.

- Негнучкість процесу та результату. Настільна гра має чітко визначені правила, які обмежують можливість внесення змін у процес під час проведення гри, через необхідність дотримання регламенту.

Висновки. Перенесення настільних ігор у площину навчання та виховання, у вищій школі, може стати якісним зрушенням у процесі освіти в загальному. Але потрібно не забувати, що настільна дидактична гра не є універсальним методом підвищення ефективності освітнього процесу у вищій школі. Це доволі специфічний механізм впливу на особистість, адже із іграми завжди складно втримати ту межу, коли вони можуть перетворити навчання на фрарс. Тому перш, ніж викладач наважиться використовувати елементи гри чи вирішить розробити власну настільну гру, треба детально вивчити цільову аудиторію, на яку педагог плануе здійснювати вплив, освітньо-наукову програму (стосовно того, які програмні результати навчання вона передбачає) та врахувати власний стиль викладання. Ну і звісно ознайомитись із ризиками, які можуть виникнути у процесі. В подальшому, у наших дослідженнях, ми плануемо створити рекомендації викладачеві щодо розробки та реалізащії освітньої настільної гри.

\section{Список літератури:}

1. Гейміфікація партисипації. Гра як інструмент залучення. URL: https://mistosite.org.ua/articles/heimifikatsiiapartysypatsii-hra-iak-instrument-zaluchennia

2. Як розробити настільну гру. URL: https://osvitoria.media/experience/yak-rozrobyty-nastilnu-gru/

3. Як створити гру? Огляд 5 етапів на прикладі «Гри для участі» муніципалітету Гельсинки. URL: https://mistosite.org.ua/articles/yak-stvoryty-hru-ohliad-5-etapiv-na-prykladi-hry-dlia-uchasti-munitsypalitetuhelsynky?locale $=u k$

4. Fleming N. (2018) Gamification: Is it game over? [online] Bbc.com. Available at: http://www.bbc.com/future/ story/20121204-can-gaming-transform-your-life

\section{References:}

1. Heymifikatsiya partysypatsiyi. Hra yak instrument zaluchennya. URL: https:/mistosite.org.ua/artitsles/ heimifikatsiia-partysypatsii-hra-iak-instrument-zaluchennia

2. Yak rozrobyty nastil'nu hru. URL: https://osvitoria.media/experientse/yak-rozrobyty-nastilnu-gru/

3. Yak stvoryty hru? Ohlyad 5 etapiv na prykladi «Hry dlya uchasti» munitsypalitetu Hel'synky. URL: https://mistosite.org.ua/artitsles/yak-stvoryty-hru-ohliad-5-etapiv-na-prykladi-hry-dlia-uchasti-munitsypalitetuhelsynky?lotsale=uk

4. Fleming N. (2018) Gamification: Is it game over? [online] Bbc.com. Available at: http://www.bbc.com/future/ story/20121204-can-gaming-transform-your-life 